\title{
Characterization of isolates of Flavobacterium psychrophilum associated with coldwater disease or rainbow trout fry syndrome I: phenotypic and genomic studies
}

\author{
Ellen Lorenzen ${ }^{1, *}$, Inger Dalsgaard ${ }^{2}$, Jean-Francois Bernardet ${ }^{3}$ \\ ${ }^{1}$ Danish Veterinary Laboratory, Hangøvej 2, DK-8200 Århus N, Denmark \\ ${ }^{2}$ Danish Institute for Fisheries Research, Fish Disease Laboratory, Royal Veterinary and Agricultural University,
} Bülowsvej 13, DK-1870 Frederiksberg C, Denmark

${ }^{3}$ Laboratoire de Virologie et d'Immunologie Moléculaires, Centre de Recherches INRA, F-78352 Jouy-en-Josas cedex, France

\begin{abstract}
Isolates of Flavobacterium psychrophilum (formerly Cytophaga psychrophila and Flexibacter psychrophilus) mainly originating from clinical outbreaks of either coldwater disease (CWD) or rainbow trout fry syndrome (RTFS) were studied for selected biochemical, physiological, morphological and genomic characteristics, and compared with previously characterized French and American strains. DNA hybridization studies showed that the Danish isolates were highly related to the type strain, F psychrophilum NCIMB $1947^{\top}$ Plasmid profiling of Danish isolates and those from other European countries revealed differences, which might be related to differences in pathogenicity. European isolates originating from clinical outbreaks of either RTFS or CWD usually harboured one plasmid of $3.2 \mathrm{~kb}$, whereas isolates originating from fish with different or no disease signs had other profiles. Phenotypically, the Danish isolates appeared very homogeneous and shared most characteristics with the type strain, and with French and American strains studied by other authors. Further studies on the importance of the plasmids and the proteolytic activities of the bacterium might help in elucidating possible virulence factors.
\end{abstract}

KEY WORDS: Flavobacterium psychrophilum - Coldwater disease - Rainbow trout fry syndrome Phenotype $\cdot$ Haemagglutination DNA-DNA hybridization - Plasmids

\section{INTRODUCTION}

Since about 1980 a disease known as rainbow trout fry syndrome (RTFS) has resulted in serious losses of rainbow trout fry in hatcheries throughout Europe (Weis 1987, Bernardet et al. 1988, Lehmann et al. 1988, Baudin-Laurencin et al. 1989, Lorenzen et al. 1991, Bruno 1992, Santos et al. 1992, Sarti et al. 1992, Toranzo \& Barja 1993). Since the 1940s, a disease named peduncle disease (Davis 1946, cited by Bullock et al. 1971), low temperature disease (Borg 1960), or (bacterial) coldwater disease (B)(CWD) (Wood \& Yasutake 1956, Borg 1960, Holt 1987, Holt et al. 1989) has been

•E-mail: el@svs.dk known in the USA, where hatchery reared sac fry and fingerlings of coho salmon Oncorhynchus kisutch appeared to be most susceptible. Several other salmonids can also be affected (Bullock et al. 1971, Schachte 1983, Amos 1985, Holt 1987), and in Japan CWD has been reported to affect yamame trout $O$. masou $(\mathrm{H}$. Wakabayashi pers. comm.) and ayu Plecoglossus altivelis (Wakabayashi et al. 1994). Apparently the same bacterium, recently renamed Flavobacterium psychrophilum (Bernardet et al. 1996) (previously Flexibacter psychrophilus (Bernardet \& Grimont 1989) and Cytophaga psychrophila (Reichenbach 1989)], is responsible for both CWD and RTFS (Baudin-Laurencin et al. 1989, Lorenzen et al. 1991).

Apart from a dark coloration of the skin and bilateral exophthalmia, the pathological changes of RTFS are 
primarily observed in the viscera of the fish, i.e. there is usually a distinct anaemia resulting in extremely pale gills, liver and kidney, an enlarged spleen, a white, fragile intestine, and a haemorrhagic, protruding anus (Baudin-Laurencin et al. 1989, Lorenzen et al. 1991, Bruno 1992, Santos et al. 1992). Fry recovering from the infection may have severe skin lesions around the dorsal fin (Baudin-Laurencin et al. 1989, Lorenzen et al. 1991) and suffer from blindness (authors' obs.). By contrast, the signs of CWD described are typically external ones, such as skin and muscle lesions on the flank, anterior to the dorsal fin or around the peduncle of fry and fingerlings [Davis 1946 (cited by Bullock et al. 1971), Wood \& Yasutake 1956, Borg 1960, Wood 1974), or erosion of the yolk skin in sac fry (Wood 1974). In chronic forms of CWD the fish may exhibit spiral swimming behaviour (Kent et al. 1989, Meyers 1989), lurdosis, and scoilosis (Conrad \& DeCew 1967).

Recently it was demonstrated that the host range of the bacterium was not only confined to salmonids. In 1989-90 Flavobacterium psychrophilum was isolated from a free-living diseased eel and from extensively cultured cyprinids exhibiting various pathological signs (Lehmann et al. 1991).

Concurrent with the occurence of RTFS in Europe, yearling (i.e. table size) rainbow trout with signs similar to those of CWD have been observed in European trout farms (Weis 1987, Lehmann et al. 1988, Dalsgaard \& Hørlyck 1990, Bruno 1992, Santos et al. 1992, Wiklund et al. 1994). In addition to the signs described for CWD from the USA, blindness, anaemia and splenomegaly may be observed. As in fry, these fish are usually systemically infected by Flavobacterium psychrophilum. Somewhat similar signs have also been found among reared brown trout Salmo trutta, Atlantic salmon Salmo salar, and whitefish Coregonus muksun and attributed to the bacterium (O. Thoresen, Norway, V. Hirvelä-Koski and T. Pohjanvirta, Finland, pers. comms.).

Apparently there is a gradual transformation as regards disease signs from RTFS to the European form of CWD depending on the size of the fish. Accordingly, fingerlings, i.e. fish between fry and table size fish, exhibit neither the typical signs of RTFS, nor those of CWD, but only show slight splenomegaly, anaemia, occasional blindness, or perhaps petechiae and haemorrhages in the viscera and the mouth region. The latter signs are indistinguishable from signs of enteric redmouth disease or viral haemorrhagic septicemia (Wood \& Yasutake 1956, authors' obs.). Furthermore, systemically infected breeding fish do not show the signs of CWD or RTFS at all, but only seem to suffer from blindness (authors' obs.). In agreement with this, Holt (1987) demonstrated Flavobacterium psychrophilum in the kidney, spleen, milt, and ovarian fluid of sexually mature adult chinook and coho salmon without clinical signs of disease.

There is evidence for the occurrence of RTFS and CWD in most European countries, but the number of characterized isolates of Flavobacterium psychrophilum is limited. A possible explanation for this could be difficulties in cultivation of the bacterium, which is relatively fastidious, thermo-sensitive, and sometimes very slow growing (Bernardet \& Kerouault 1989, Lorenzen \& Karas 1992, Lorenzen 1993). A detailed characterization of isolates originating from different countries is evidently necessary in order to clarify whether we are dealing with the same pathogen in Europe, USA, and Japan.

The present study on Flavobacterium psychrophilum comprised 32 Danish isolates and 20 isolates from other European countries, and the objective was to compare the isolates with regard to biochemistry, physiology, morphology, chromosomal DNA, and plasmids. The type strains F. psychrophilum NCIMB $1947^{\top}$ and Flavobacterium columnare NCIMB $2248^{\top}$ were included as references, the latter, however, only for the genomic studies. An additional aim was to compare Danish isolates from clinical outbreaks of RTFS with those originating from table size fish suffering from CWD to establish whether isolates within Denmark constituted a homogeneous group, independent of fish size, pathological signs, and fish species.

\section{MATERIALS AND METHODS}

Bacterial isolates. The bacterial isolates included in the study are listed in Table 1. Not all isolates were examined for all of the characteristics described below, but at least the following characters have been studied for all strains: colony morphology, cell morphology, motility, ability to grow continuously on blood agar, reactivity with the API ZYM gallery, presence of catalase, production of cytochrome oxidase and flexirubin, and ability to absorb Congo red and to hydrolyze starch and tyrosine. According to Bernardet et al. (1990), examination of these characters is considered sufficient for differentiation of Flavobacterium psychrophilum from other valid Flavobacterium, Flexibacter and Cytophaga species

Cultivation. The bacteria were grown on a medium which was enriched with respect to protein concentration compared to the original Cytophaga-medium described by Anacker \& Ordal (1955). The modified medium, henceforth referred to as Anacker \& Ordal's agar/broth enriched (AOAE/AOBE), consisted of $0.7 \%$ (Oxoid) or $1.0 \%$ (Gibco) agar if any, $5 \%$ newborn calf serum, $0.5 \%$ tryptone (Difco), $0.05 \%$ yeast extract, $0.02 \%$ sodium acetate, and $0.02 \%$ beef extract; the $\mathrm{pH}$ 
Table 1. Isolates of Flavobacterium psychrophilum included in the study

\begin{tabular}{|c|c|c|c|c|c|c|}
\hline Code & Isolate & Source: species & Tissue & Clinical signs & Geographic orıgin & Year \\
\hline$F C^{\top}$ & F. columnare NCIMB $2248^{\top}$ & Chinook salmon & Kidney & - & Washington, USA & 1955 \\
\hline Fp $p^{\top}$ & F. psychrophilum NCIMB $1947^{\top}$ & Coho salmon & Kidney & CWD & Washington, USA & Unknown \\
\hline 1 & $910611-1$ & Rbt: fry & Spleen & Costiasıs ${ }^{d}$ & Denmark & 1991 \\
\hline 2 & $911209-2$ (NCIMB 13384) & Rbt. fry & Spleen & RTFS & Denmark & 1990 \\
\hline 3 & $910803-1$ & Rbt, fry & Kidney & RTFS & Denmark & 1991 \\
\hline 4 & $910516-1$ & Rbt, fry & Spleen & IPNV $\mathrm{b}$ & Denmark & 1991 \\
\hline 5 & $911209-1$ (NCIMB 13383) & Rbt, fry & Spleen & RTFS & Denmark & 1990 \\
\hline 6 & $910619-1$ & Rbt, fry & Spleen & RTFS & Denmark & 1991 \\
\hline 7 & $910614-2$ & Rbt, young & Skin & CWD & Denmark & 1991 \\
\hline 8 & $911126-2$ & Rbt, young & Spleen & CWD & Denmark & 1991 \\
\hline 9 & $911126-3$ & Rbt, young & Skin & CWD & Denmark & 1991 \\
\hline 10 & $911009-3$ & Rbt, young & Skin & CWD & Denmark & 1991 \\
\hline 11 & $910614-3$ & Rbt, young & Kidney & CWD & Denmark & 1991 \\
\hline 12 & $910614-5$ & Rbt, young & Eye & CWD & Denmark & 1991 \\
\hline 13 & $900406-1$ & Rbt, young & Kidney & CWD & Denmark & 1990 \\
\hline 14 & $900530-4 / 2$ & Rbt, fry & Intestine & RTFS & Denmark & 1990 \\
\hline 15 & $930210-1$ & Rbt, breeding fish & Eye & $(C W D)^{c}$ & Denmark & 1993 \\
\hline 16 & $930223-2$ & Rbt, young & Kidney & CWD/RTFS & Denmark & 1993 \\
\hline 17 & $930305-1$ & Rbt, breeding fish & Kidney & $(C W D)^{c}$ & Denmark & 1993 \\
\hline 18 & $930310-1$ & Rbt fry & Spleen & RTFS & Denmark & 1993 \\
\hline 19 & $930324-1$ & Rbt, young & Kidney & CWD & Denmark & 1993 \\
\hline 20 & $930407-1$ & Rbt, young & Spleen & CWD/RTFS & Denmark & 1993 \\
\hline 21 & $930413-1$ & Rbt, young & Skin & CWD & Denmark & 1993 \\
\hline 22 & $930427-2$ & Rbt, fry & Spleen & RTFS & Denmark & 1993 \\
\hline 23 & $930610-1$ & Rbt, fry & Spleen & RTFS & Denmark & 1993 \\
\hline 24 & $930611-2$ & Rbt, fry & Spleen & RTFS & Denmark & 1993 \\
\hline 25 & $930616-1$ & Rbt, fry & Spleen & RTFS & Denmark & 1993 \\
\hline 26 & $930909-2$ & Rbt, fry & Spleen & RTFS & Denmark & 1993 \\
\hline 27 & $930929-2$ & Rbt, young & Spleen & CWD/RTFS & Denmark & 1993 \\
\hline 28 & $931008-1$ & Rbt, young & Spleen & CWD/RTFS & Denmark & 1993 \\
\hline 29 & $931116-2$ & Rbt, young & Spleen & CWD/RTFS & Denmark & 1993 \\
\hline 30 & $931130-6$ & Rbt, young & Spleen & CWD/RTFS & Denmark & 1993 \\
\hline 31 & $931216-2$ & Rbt, young & Spleen & CWD/RTFS & Denmark & 1993 \\
\hline 32 & $940114-6$ & Rbt, young & Spleen & CWD & Denmark & 1994 \\
\hline a & UPl $293^{\circ}$ & Rbt, fry & Spleen & RTFS & Dorset, UK & 1992 \\
\hline b & WIL $293^{1}$ & Rbt, fry & Spleen & RTFS & Devon, UK & 1992 \\
\hline c & PT $4.1^{2}$ & Rbt, fingerling & Spleen & RTFS & Spain & 1992 \\
\hline$d$ & $16 / 90^{3}$ & Tench $\cdot$ & Spleen & Haemorrhage & Germany & 1990 \\
\hline e & TG $28 / 86^{4}$ & Rbt, young & Blister & CWD & Touraine, France & 1986 \\
\hline $\mathrm{f}$ & Tours $5 / 1^{4}$ & Carp $\cdots$ & Gills & Gill injury & Touraine, France & 1992 \\
\hline g & $11522^{5}$ & Rbt, fry & Spleen & RTFS & France & 1993 \\
\hline $\mathrm{h}$ & $11524^{5}$ & Rbt, fry & Spleen & RTFS & France & 1993 \\
\hline $\mathrm{i}$ & Fi $88 / 93^{\circ}$ & Rbt, fry & Spleen & RTFS & Switzerland & 1993 \\
\hline & Fi $147 / 93^{6}$ & Rbt, young & Spleen & RTFS/CWD & Switzerland & 1993 \\
\hline $\mathrm{k}$ & Fi $171 / 93^{6}$ & Rbt, fingerling & Spleen & RTFS $^{d}$ & Switzerland & 1993 \\
\hline l & Fi $196 / 93^{6}$ & Rbt, fingerling & Spleen & $\mathrm{ICH}^{\mathrm{e}}$ & Switzerland & 1993 \\
\hline $\mathrm{m}$ & Fi $206 / 93^{6}$ & Rbt, fingerling & Spleen & None & Switzerland & 1993 \\
\hline $\mathrm{n}$ & $\mathrm{Fi} 332 / 92^{6}$ & Rbt, fingerling & Spleen & RTFS & Switzerland & 1992 \\
\hline 0 & $255 / 93^{7}$ & Brown trout $\cdots$ & Skin & Skin lesion & Finland & 1993 \\
\hline $\mathrm{p}$ & $3441 / 93^{7}$ & $\mathrm{Rbt}$, young & Skin & Skin lesion & Finland & 1993 \\
\hline $\mathrm{q}$ & K $129-3 / 91^{8}$ & Whitefish $\cdots \cdot \cdot$ & Skin & Skin lesion & Finland & 1991 \\
\hline I & K $129-4 / 91^{8}$ & Whitefish & Skin & Skin lesion & Finland & 1991 \\
\hline & $S 231^{9}$ & Rbt, fry & Spleen & Pale gills & Northern Ireland & 1993 \\
\hline $\mathrm{t}$ & $386 / 94^{10}$ & Brown trout, parr & Skin & Skin lesion & Norway & 1994 \\
\hline \multicolumn{7}{|c|}{$\begin{array}{l}\text { Isolates were kindly provided by the following scientists: } \\
\text { }{ }^{1} \text { r Rachel Rangdale, Fish Disease Laboratory, Weymouth, UK; }{ }^{2} \text { Drs A. E. Toranzo \& J. L. Barja, University of Santiago de Com- } \\
\text { postela, Spain; }{ }^{3} \text { Dr Dieter Mock, Landesanstalt für Fischerei, Nordrhein-Westfalen, Germany; }{ }^{4} \text { Dr Jean-Francois Bernardet, } \\
\text { INRA, Jouy-en-Josas, France; }{ }^{5} \text { Dr Martine Vigneulle, CNEVA, Plouzane, Brest, France; }{ }^{6} \text { Dr Thomas Wahli, Universität Bern, } \\
\text { Switzerland; }{ }^{7} \text { Dr Varpu Hirvelä-Koski, National Veterinary Institute, Oulu, Finland; }{ }^{8} \text { Dr Tarja Pohjanvirta, National Veterinary } \\
\text { and Food Research Institute, Kuopio, Finland; }{ }^{9} \text { Dr Joyce McCormick, Fish Disease Laboratory, Belfast, Northern Ireland; } \\
{ }^{10} \text { Dr Ove Thoresen, Central Veterinary Laboratory, Oslo, Norway }\end{array}$} \\
\hline \multicolumn{7}{|c|}{$\begin{array}{l}\cdot \text { Rbt: rainbow trout, }{ }^{-} \text {tench: Tinca tinca, }{ }^{\cdots} \text { carp: Cyprinus carpio, } \cdots \text { brown trout: Salmo trutta lacustris, } \cdots \cdots \text { whitefish: Core- } \\
\text { gonus muksun }\end{array}$} \\
\hline \multicolumn{3}{|c|}{ 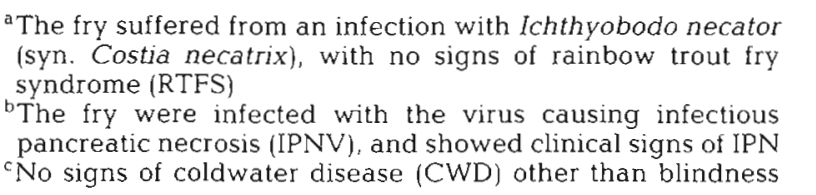 } & \multicolumn{4}{|c|}{$\begin{array}{l}{ }^{\mathrm{d}} \text { The fingerlings showed clinical signs of RTFS, and were also } \\
\text { infected with Ichthyobodo necator and with Renibacterium } \\
\text { salmoninarum, the causative agent of bacterial kidney } \\
\text { disease } \\
\text { e The fingerlings showed very few signs of RTFS, and were } \\
\text { recovering from an infection by Ichthyophthirius multifiliis }\end{array}$} \\
\hline
\end{tabular}


was adjusted to between 7.2 and 7.4 (Lorenzen 1993). For the biochemical and physiological studies described below, AOAE/AOBE was used as the basal medium and all incubations were performed at 15 to $17^{\circ} \mathrm{C}$ unless otherwise stated.

Morphological studies. The bacteria were grown on AOAE for 48 to $72 \mathrm{~h}$ whereupon colony morphology was observed visually and with a stereo microscope $(\times 100)$. Gliding movement and cell morphology was studied by phase contrast microscopy $(\times 400)$ of wet mounts and hanging drop preparations of cells grown in $A O B E$ on an orbital shaker for 48 to $72 \mathrm{~h}$. Gram staining was performed on cells grown on AOAE for $48 \mathrm{~h}$. Electron microscopy (EM) was performed on a pool of serum from 10 naturally infected fry and on a bacterial isolate originating from one of these fry (911209-1). Bacteria/serum was fixed in $1.5 \%$ glutaraldehyde in $0.1 \mathrm{M}$ cacodylate buffer (pH 7.2). Following fixation bacteria or serum was centrifuged and the cell pellet resuspended in $1.5 \%$ Noble agar (Difco). Small blocks of the solidified agar were postfixed in $1 \% \mathrm{OsO}_{4}$, impregnated in $2 \%$ uranylacetate, and dehydrated in alcohol and propylene oxide before embedding in Vestopal-W. Ultrathin sections were cut and stained with magnesium uranylacetate (Frasca \& Parks 1965) and lead citrate (Reynolds 1963). EM was carried out at primary magnifications of $\times 7000$ and $\times 20000$.

Physiological studies. The ability of isolates to grow at different temperatures was studied by incubation of inoculated AOBE tubes in a water bath at 5, 20 and $25^{\circ} \mathrm{C}$, respectively. The broth cultures were inspected daily for changes in turbidity. Growth was finally recorded after $10 \mathrm{~d}$. Checks for contamination were made by subcultivating each tube on AOAE and blood agar. The ability of isolates to grow at different $\mathrm{NaCl}$ concentrations was studied by inoculation of $\mathrm{AOBE}$ tubes supplemented with $0,0.5$ and $1.0 \% \mathrm{NaCl}$, respectively, and incubating these for $10 \mathrm{~d}$ at 15 to $17^{\circ} \mathrm{C}$. Growth of Flavobacterium psychrophilum and contamination was tested for as described above.

Biochemical studies. Flexirubin-type pigments: The presence of flexirubin-type pigments was demonstrated by flooding colonies ( 48 to $72 \mathrm{~h}$ ) with alkali, i.e. $10 \% \mathrm{KOH}$ (Reichenbach \& Dworkin 1981), and watching for a colour change from yellow to orange.

Galactosamine glycan: Isolates were examined for an extracellular galactosamine glycan as demonstrated for Flavobacterium columnare (Johnson \& Chilton $1966)$ by recording the colour of colonies grown for $8 \mathrm{~d}$ on AOAE supplemented with $0.003 \%$ Congo red (Ishiguro et al. 1985).

Respiratory metabolism: Presence of catalase was tested for by adding a few microliters of $30 \% \mathrm{H}_{2} \mathrm{O}_{2}$ (Merck) to colonies 24 to $72 \mathrm{~h}$ old. Cytochrome oxidase was demonstrated in similar colonies by use of impregnated filter paper strips (Hoffmann-La Roche) according to the manufacturer's instructions. Ability to reduce nitrate was tested for in $A O B E$ containing $0.1 \%$ potassium nitrate (Bullock 1972). Production of hydrogen sulphide was tested for in inoculated AOBE by suspending filter paper strips impregnated with $10 \%$ lead acetate [Pacha \& Porter 1968, Public Health Laboratory Service 1976 (modified after Cowan 1974)] or commercially available lead acetate filter paper (Merck) above the broth. Filter papers were daily observed for dark coloration during a $10 \mathrm{~d}$ incubation period.

Carbohydrate/alcohol metabolism: The ability to degrade simple and more complex carbohydrates or alcohols (glucose, glycerol, glycogen, inulín, saccharose) was tested by incubation for 8 to $10 \mathrm{~d}$ on $\mathrm{AOAE}$ siants supplemented with $0.2 \%$ bromothymol blue as described by Bernardet (1989). The ability to degrade starch was determined during a $6 \mathrm{~d}$ incubation period as described by Bullock (1972).

Protein metabolism: Gelatin hydrolysis was tested for by inoculating isolates onto AOAE supplemented with $1 \%$ gelatin (w/v); casein hydrolysis was tested for on AOAE containing $10 \%$ (v/v) skimmed milk; hydrolysis of tyrosine and pigment production on tyrosine agar was studied on AOAE supplemented with $0.5 \%$ L-tyrosine ( $\mathrm{w} / \mathrm{v}$ ) and $0.2 \%$ additional agar, the latter in order to compensate for the softening effect of tyrosine. After an 8 to $10 \mathrm{~d}$ incubation the plates were inspected for clearing and/or pigmentation around colonies. The tests described above were modified after Pacha \& Porter (1968).

Lipid metabolism: Production of lipase was tested for by inoculation on AOAE supplemented with $1 \%$ tributyrin (glycerol tributyrate) (w/v) emulsified in $0.1 \%$ polyvinyl alcohol (Mourey \& Kilbertus 1976) followed by inspection for clearing around colonies after 8 to $10 \mathrm{~d}$ of incubation; lecithinase activity was studied on AOAE with $0.5 \%(\mathrm{w} / \mathrm{v})$ neutralized egg lecithin added (Willis 1960); esterase production was determined on AOAE supplemented with $1 \%$ Tween $80(\mathrm{w} / \mathrm{v})$ (modified from Sierra 1957). The presence of lecithinase and esterase was demonstrated by formation of an opaque halo around colonies following an 8 to $10 \mathrm{~d}$ incubation.

Lysis of bacterial cells: Washed and autoclaved cells of a Danish strain of Aeromonas hydrophila (9109263/12), Aeromonas salmonicida (911029-1/1), Pseudomonas sp. (920114-2/2), Yersinia ruckeri (910926-3/1), and Escherichia coli (39R861) were added to AOAE. Clearing around colonies of Flavobacterium psychrophilum on such plates following 8 to $10 \mathrm{~d}$ of incubation indicated lysis according to Pacha \& Porter (1968). 
Lysis of DNA: The presence of DNase was studied by inoculating bacteria onto AOAE supplemented with $0.03 \%$ DNA (Difco Bacto-DNA) and $0.0075 \%$ toluidine blue (modified after Lior \& Patel 1987). The presence of DNase was revealed by a change in colour from blue to bright red around and beneath colonies after 8 to $10 \mathrm{~d}$ of incubation.

Lysis of blood cells: Presence of haemolysin was tested for on AOAE plates supplemented with $5 \%$ citrated calf blood and $5 \%$ heparin-stabilized rainbow trout blood cells, respectively. To inhibit haemolysis of the blood cells due to the lower osmolarity of AOAE (compared to blood), $0.5 \% \mathrm{NaCl}$ was also added. The presence of haemolysin was demonstrated by clearing around and/or beneath colonies after 8 to $10 \mathrm{~d}$ incubation.

Growth on blood agar: The ability to grow on blood agar (Gibco blood agar base supplemented with $5 \%$ citrated calf blood) was investigated by inoculation followed by inspection for growth during an 8 to $10 \mathrm{~d}$ incubation period.

Haemagglutinin test: The presence of haemagglutinin or haemolysin was studied using a microdilution method modified after Titball \& Munn (1981): membrane-filtered $(0.22 \mu \mathrm{m})$ supernatant from centrifuged $(60 \mathrm{~min}, 4000 \times g) 48 \mathrm{~h}$ old broth cultures, the broth culture itself and AOBE were diluted with saline $10.9 \%$ $\mathrm{NaCl}$ in four 2-fold steps in a microtiter plate. Washed rainbow trout blood cells diluted 1:100 in $0.9 \% \mathrm{NaCl}$ were added in an equal volume $(50 \mu \mathrm{l})$ and the microtiter plate was incubated at $25^{\circ} \mathrm{C}$ on an orbital shaker for $2 \mathrm{~h}$. The interaction between blood cells and the supernatant (containing possible extracellular products, ECPs), the bacterial cells or AOBE, was recorded using an inverted microscope $(\times 37.5)$. To test if the observed effect was heat stable, autoclaved $\left(121^{\circ} \mathrm{C}, 60 \mathrm{~min}\right) \mathrm{ECPs}$ were examined in parallel. The effect on calf blood cells was tested in a similar way, using citrated calf blood. Also, as AOBE contains $5 \%$ newborn calf serum (NBS), the effect of diluted NBS on trout blood cells was also studied.

Enzyme production: The semiquantitative micromethod, API ZYM (bioMérieux SA, Marcy-l'Etoile, France) was used to test 19 enzymatic activities in addition to the ones already described. The strips were incubated for 16 to $18 \mathrm{~h}$ at 15 to $17^{\circ} \mathrm{C}$.

Antibiotic sensitivity: Minimal inhibitory concentrations (MIC) of the drugs most commonly used in Danish fish farms, i.e. sulphadiazin/trimethoprim [in the laboratory was used co-trimoxazole (A/S Rosco Diagnostica, Denmark), sulphamethoxazole:trimethoprim 20:1], oxolinic acid (Sigma O-0877), and oxytetracycline (Rosco), were determined by the agar dilution method (modified after Sahm \& Washington II, 1991) using 2-fold serial dilutions of the drugs in $\operatorname{AOAE}\left(50\right.$ to $0.05 \mathrm{\mu g} \mathrm{m}^{-1}$ ), an inoculum of approximately $2 \times 10^{4} \mathrm{CFU}$ in $20 \mu \mathrm{l}$ and 2 to $3 \mathrm{~d}$ incubation at 15 to $17^{\circ} \mathrm{C}$. The MIC tests were performed in 24-well trays. Minimal bactericidal concentrations $(\mathrm{MBC})$ of oxolinic acid and oxytetracycline were determined by a broth dilution method (modified after NCCLS Document M 26-T, Vol.12 no.19 1992), using serial 2-fold dilutions of the drugs in AOBE (500 to $0.3 \mu \mathrm{g} \mathrm{ml}^{-1}$ ) in a microtiter tray. The final inoculum density in the wells was approximately $10^{8} \mathrm{CFU}$ $\mathrm{ml}^{-1}$. Growth of Flavobacterium psychrophilum was tested by inoculation from each well onto AOAE and blood agar following $3 \mathrm{~d}$ incubation at 15 to $17^{\circ} \mathrm{C}$.

DNA-DNA hybridization. The DNA of selected Danish isolates (nos. 2, 4, 5, 7,9\&10) plus the 2 reference strains was extracted, purified and sheared as described by Brenner et al. (1982). The DNA of the type strain, Flavobacterium psychrophilum NCIMB $1947^{\mathrm{T}}$, was labelled by nick translation with tritium-labelled nucleotides (Amersham International) according to Grimont et al. (1980) using a commercial nick translation kit (Amersham International). The DNA relatedness between the labelled DNA of the type strain and the unlabelled DNA of the isolates was measured by the S1 nuclease-DE81 method (Popoff et al. 1981).

Plasmid profiling. Plasmids were isolated by use of the method described by Kado \& Liu (1981). The DNA extracts were subjected to submarine electrophoresis in a $1.5 \%$ agarose gel (SeaKem ${ }^{R}$, GTG-Agarose) and $1 \times$ TAE-buffer (Maniatis et al. 1989). Plasmids appeared after 2 to $3 \mathrm{~h}$ at 8 to $9 \mathrm{~V} \mathrm{~cm}^{-1}$ using a mini-gel electrophoresis unit (gel size of $7 \times 8.5 \mathrm{~cm}^{2}$ ). Visualization was made by staining with ethidium bromide (Sigma, $2 \mu \mathrm{g} \mathrm{ml}^{-1}$ distilled water or $3 \mu \mathrm{g} \mathrm{ml} \mathrm{m}^{-1} \mathrm{gel}$ ) followed by exposure to UV-light (254 $\mathrm{nm}$ ) (Olsen et al. 1990). Approximate molecular size of the plasmids was estimated from the migration patterns of supercoiled plasmids in 2 reference strains of Escherichia coli, V517 (Macrina et al. 1978) and 39R861 (Threlfall et al. 1986), using the regression equation recommended by Rochelle et al. (1985).

\section{RESULTS}

\section{Morphological studies}

Colonies grown for 48 to $72 \mathrm{~h}$ on AOAE were opaque, yellow, circular, convex, non-adherent, smooth and shiny and had a blue-green iridescent pattern when studied in a stereo microscope. Generally only colonies with regular edges were found, but on freshly (hours) prepared medium, colonies might appear more or less spreading. The isolates had a characteristic 'cheeselike' odour, and the cells exhibited a slow, gliding movement in wet mounts as well as in hanging drop 
preparations. Cells were Gram-negative rods, but morphology and size of the bacteria was more easily studied in wet mount preparations, where the cells appeared as long, slender rods $(0.2-0.5 \mu \mathrm{m} \times 3-10 \mu \mathrm{m})$, the length depending on the age of the colonies (cells became shorter and thicker with age). Cells grown in broth usually were longer than cells grown on agar.

Electron microscopic studies revealed a typical Gram-negative type cell wall. Cells were rod-shaped with tapered ends (approximately $0.2-0.4 \mu \mathrm{m} \quad x$ $2.0-3.0 \mu \mathrm{m}$ ) and showed some degree of 'flexibility', i.e. some of them appeared curved, like an $\mathrm{S}$ or like a $\mathrm{V}$. The cells were covered by a mucoid layer without a discernible substructure, and occasionally the presumably detached surface layer formed tubular structures. No fimbriae or flagellae were visible. A few mesosomes were seen inside the cells.

\section{Physiological studies}

All of the isolates ( 1 to 14 ) included in the physiological studies and the type strain $\mathrm{Fp}^{\mathrm{T}}$ grew well at 5 and $20^{\circ} \mathrm{C}$, whereas none was able to grow at $25^{\circ} \mathrm{C}$. Like the type strain, all isolates except one were able to grow in AOAE supplemented with $0.0 \%$ and $0.5 \%$ $\mathrm{NaCl}$, but not in medium containing $1.0 \% \mathrm{NaCl}$.

\section{Biochemical studies}

All isolates were examined for the following characters and gave the same results as the type strain $\mathrm{Fp}^{\mathrm{T}}$ : they produced flexirubin, did not absorb Congo red, were faintly positive for catalase and cytochrome oxidase, did not hydrolyze starch, and hydrolyzed tyrosine without production of pigment. The API ZYM test demonstrated the presence of lipolytic and proteolytic enzymes, whereas enzymes involved in metabolism of the carbohydrates could not be detected. The results of the API ZYM test were comparable to those described for 2 reference strains and 5 French isolates by Bernardet \& Kerouault (1989). None of the isolates was able to grow continuously on common blood agar. Isolates nos. 1 to 14 were studied for some additional characters and the results were similar to those of the type strain $\mathrm{Fp}^{\top}$, with one exception: production of $\mathrm{H}_{2} \mathrm{~S}$ of the Danish isolates was sparse, whereas it was clearly positive for the type strain, and it seemed to some degree to depend on the lead acetate filter paper used (commercially produced versus laboratory made). The isolates did not reduce nitrate, but hydrolyzed gelatin, casein and DNA; they also produced lipase, lecithinase and esterase. The bacteria were able to lyse the 5 bacterial species tested, and showed increased growth on AOAE supplemented with autoclaved cells compared to AOAE alone. They also hemolysed calf and rainbow trout blood cells partially, and grew better on AOAE supplemented with calf/fish blood cells than on AOAE alone. They were not able to produce acid from the carbohydrates/alcohols tested.

The hemagglutinin-test with $\mathrm{Fp}^{\top}$ and isolates 1 to 14 showed that apparently the bacteria possessed some kind of specific haemagglutinin as revealed by a partial agglutination of rainbow trout erythrocytes (in dilution 1:2, only), but not those of cattle. ECPs and complete broth culture reacted similarly with the erythrocytes, consequently the agglutinin also occurred in the ECPs alone. Autoclaved ECPs did not show any reactivity. The effect on trout blood cells of newborn calf serum (NBS) diluted 1:128 and 1:256 was not an agglutination like the one observed with the ECPs, but rather a kind of forced cell sedimentation. A similar sedimentation was observed with ECPs of Yersinia ruckeri in all dilutions tested, and with AOBE diluted 1:4 (partly in dilution 1:2), corresponding to a dilution of NBS of 1:80. There was no such effect of AOBE on calf blood cells. The effect of the ECPs of Aeromonas salmonicida was a clear haemolysis. The sedimenting effect of NBS, AOBE and ECPs of Y. ruckeri was considered to be the result of some kind of non-specific interaction between protein and rainbow trout blood cells.

Studies on the sensitivity to selected antibiotics included the Danish isolates nos. 1 to 14 and $\mathrm{Fp}^{\top}$. For the MIC test, isolates 26 to 32 were also included. The results of the $\mathrm{MIC}$ determinations are presented in Table 2 . The $\mathrm{MBC}$ values ( $\mu \mathrm{g} \mathrm{ml}^{-1}$ ) were as follows: (1) For oxytetracycline: mode $=3.5$, mean $=4.4$, MBC50 $=$ $2.3, \mathrm{MBC} 90=4.7$, and range $=1.2$ to 18.8 ; (2) For oxolinic acid: mode $=15.6$, mean $=133.6, \mathrm{MBC} 50=$ $31.1, \mathrm{MBC} 90=500$, and range $=11.7$ to 500 .

\section{DNA-DNA hybridization}

The DNA hybridization studies demonstrated that the 6 Danish isolates examined (nos. 2,4,5,7,9 \& 10) were more than $70 \%$ ( 73 to $89 \%$ ) related to the type strain NCIMB $1947^{\top}$ and should thus be regarded as belonging to the species Flavobacterium psychrophilum. In contrast, the type strain of $F$. columnare, NCIMB $2248^{\mathrm{T}}$, which belongs to another bacterial species (Bernardet \& Grimont 1989), was only $3 \%$ related to $F$. psychrophilum NCIMB $1947^{\top}$.

\section{Plasmid profiling}

The results of plasmid analyses of all the isolates and of $\mathrm{Fp}^{\top}$ and $\mathrm{FC}^{\top}$ are presented in Table 3 and Fig. 1. The 
Table 2. Minimum inhibitory concentrations (MIC) of various antibiotics. Distribution, mode, mean, MIC50, MIC90, and range of MIC values ( $\mu \mathrm{g} \mathrm{ml}^{-1}$ ) for 21 Danish isolates of Flavobacterium psychrophilum

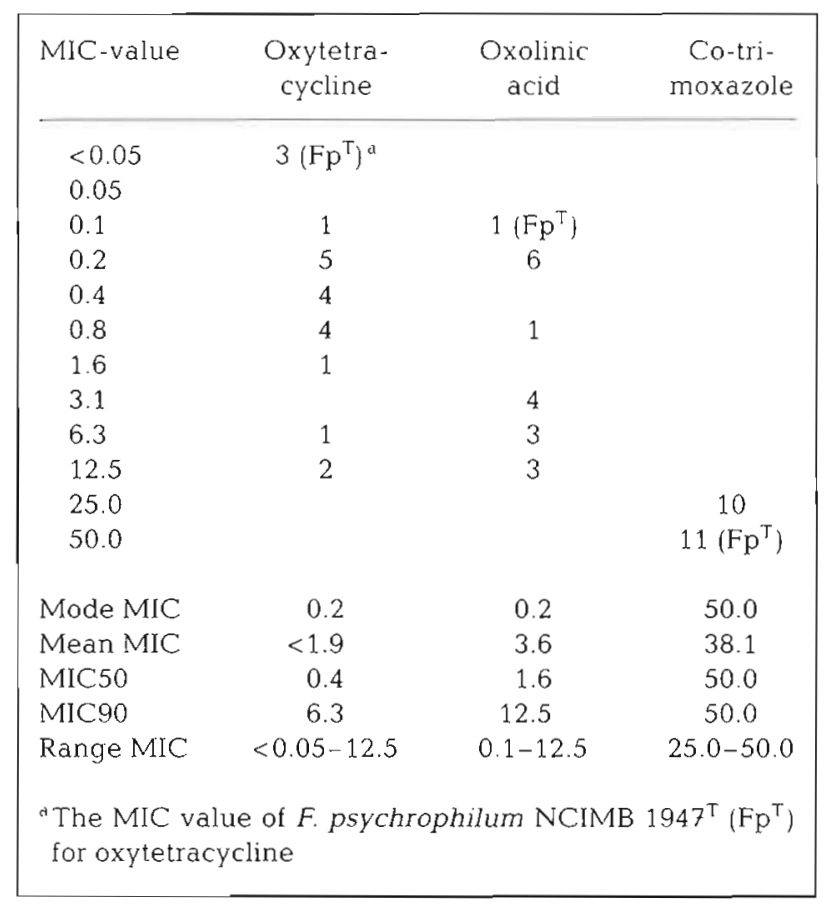

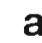

a

2

3

4

5

6

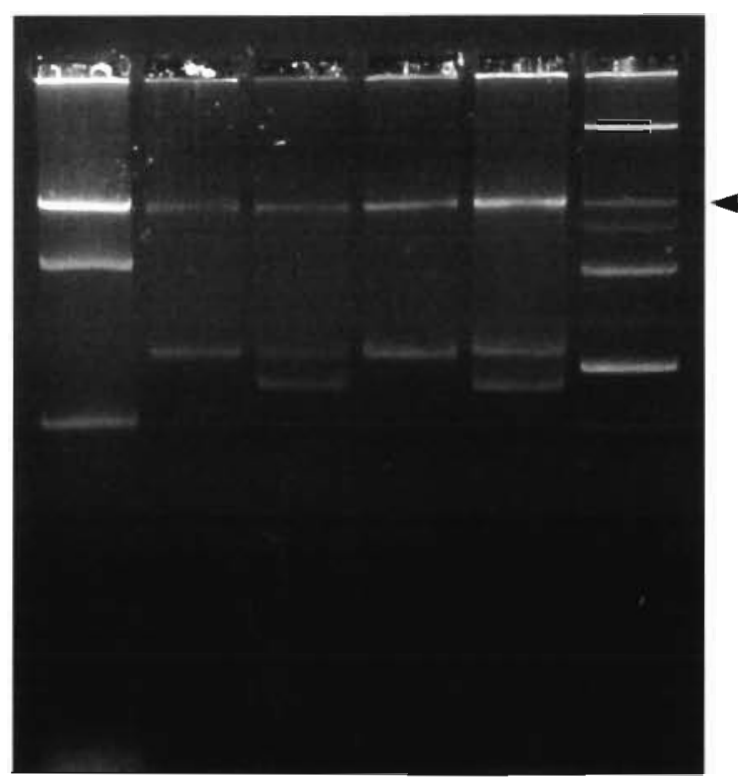

Table 3. Plasmid analysis of 25 Danish isolates, 20 isolates from other European countries and 2 reference strains, Flavobacterium psychrophilum NCIMB $1947^{\mathrm{T}}\left(\mathrm{Fp}^{\mathrm{T}}\right)$, and F. columnare NCIMB $2248 \mathrm{~T}\left(\mathrm{FC}^{\mathrm{T}}\right)$

\begin{tabular}{|c|c|c|c|}
\hline \multirow[t]{2}{*}{ Plasmid $(\mathrm{kb})^{\mathrm{a}}$} & \multicolumn{3}{|c|}{ Isolate/strain $\longrightarrow$} \\
\hline & $\begin{array}{l}\text { Danish } \\
\text { isolates }^{b}\end{array}$ & $F p^{\top} \quad F C^{\top}$ & $\begin{array}{l}\text { Isolates from other } \\
\text { European countries }\end{array}$ \\
\hline 3.2 & $21^{b}$ & & 14 \\
\hline 2.4 & & 1 & \\
\hline $5.7+2.2$ & & & $1^{c}$ \\
\hline $3.2+2.6$ & $2^{d}$ & & \\
\hline 0 & $2^{e}$ & 1 & $5^{1}$ \\
\hline \multicolumn{4}{|c|}{$\begin{array}{l}{ }^{b} \text { Numbers indicate number of isolates with a plasmid/ } \\
\text { plasmids of the size indicated to the left in the table }\end{array}$} \\
\hline \multicolumn{4}{|c|}{${ }^{C}$ Isolate f $\quad$ Isolates 1 and 4} \\
\hline \multicolumn{2}{|c|}{ dIsolates 15 and 17} & \multicolumn{2}{|c|}{$\begin{array}{l}\text { eIsolates } 1 \text { and } 4 \\
\text { 'Isolates } \mathrm{d}, \mathrm{l}, \mathrm{O}, \mathrm{q}, \mathrm{r}\end{array}$} \\
\hline
\end{tabular}

sizes of the plasmids calculated from the present study are very approximate, as the method applied (Kado \& Liu 1981) and the size of the gel allowed only rough estimations. Plasmid profiling showed that most of the Danish isolates and those from other European countries had one small plasmid of approximately $3.2 \mathrm{~kb}$,

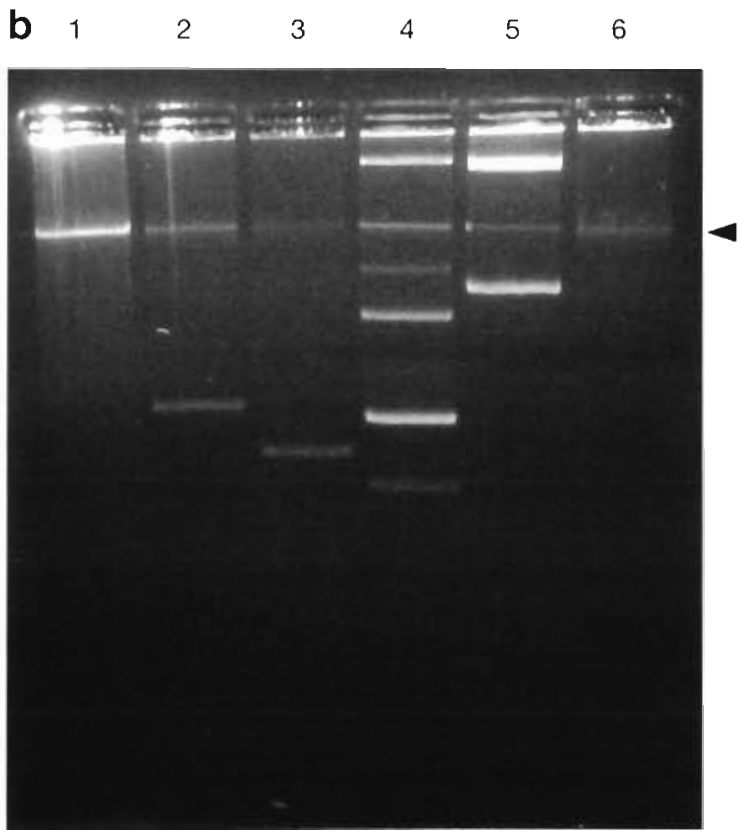

Fig. 1. Types of plasmid profiles found among 25 Danish isolates, 20 isolates from other European countries and 2 reference strains, Flavobacterium psychrophilum NCIMB $1947^{\mathrm{T}}$, and F. columnare NCIMB $2248^{\top}$. (a) Lane 1 . French isolate $\mathrm{f}(2.2+5.7 \mathrm{~kb})$. Lane 2: Danish isolate 2 (3.2 kb). Lane 3: Danish isolate $17(2.6+3.2 \mathrm{~kb})$. Lane 4: Danish isolate 5 (3.2 kb). Lane 5: Danish isolate $15(2.6+3.2 \mathrm{~kb})$. Lane 6: Escherichia coli V517 $(2.1,2.7-3.0,3.9,5.1-5.5,7.2,54 \mathrm{~kb})$. (b) Lane 1: German isolate d (0 plasmids). Lane 2: Danish isolate 2 (3.2 kb). Lane 3: F. psychrophilum NCIMB $1947^{\top}(2.4 \mathrm{~kb})$. Lane 4: E. coli V517 (2.1, 2.7-3.0, 3.9, 5.1-5.5, 7.2, $54 \mathrm{~kb}$ ). Lane 5: E. coli 39R816 $\left(7.0,36-63-147 \mathrm{~kb}\right.$ ). Lane 6: F. columnare NCIMB $2248^{\mathrm{T}}$ (0 plasmids). Arrowhead: Chromosomal band of approximately $21 \mathrm{~kb}$ 
whereas the plasmid of the type strain of Flavobacterium psychrophilum, NCIMB $1947^{\Upsilon}$, was smaller (approximately $2.4 \mathrm{~kb}$ ). Two Danish isolates harboured a plasmid of $2.6 \mathrm{~kb}$ in addition to the $3.2 \mathrm{~kb}$ plasmid, and one French isolate had also 2 plasmids, but of 5.7 and $2.2 \mathrm{~kb}$. No plasmids were detected in the type strain of $F$. columnare, NCIMB 2248 ${ }^{T}$, or in 2 Danish and 5 isolates of F. psychrophilum from other European countries. The 5 different plasmid profiles are shown in Fig. 1. The band at about $21 \mathrm{~kb}$ demonstrated in all isolates, reference strains and the molecular weight markers was considered chromosomal DNA as it tended to disappear on prolonged temperature treatment during purification (Kado \& Liu 1981) and came out as a smear by restriction endonuclease digestion using HindIII (results not presented).

\section{DISCUSSION}

The present studies on DNA relatedness between 6 of the Danish isolates and the type strain NCIMB $1947^{\mathrm{T}}$ confirmed that the isolates belonged to the species Flavobacterium psychrophilum. The results on biochemical, morphological and physiological studies indicated that the Danish isolates as well as the isolates from other European countries, originating from fish with more or less pronounced signs of CWD or RTFS, were very homogeneous and that they were similar to those from the USA. (Pacha \& Porter 1968, Holt 1987) and France (Bernardet \& Kerouault 1989). Plasmid analysis, however, revealed some differences.

By plasmid analysis Holt (1987) demonstrated a plasmid of similar size to the one found in the type strain NCIMB $1947^{\mathrm{T}}(2.4 \mathrm{~kb})$ in 7 out of 15 strains. The 7 strains were isolated from coho salmon and cutthroat or steelhead trout with typical signs of BCWD/ peduncle disease. In the present study it was noteworthy that isolates from clinical outbreaks of RTFS or CWD had one plasmid of approximately $3.2 \mathrm{~kb}$, whereas 2 isolates from chronically infected fish had an additional plasmid of $2.6 \mathrm{~kb}$. The isolates without plasmids or with 2 plasmids of different size generally originated from fish without classical signs of RTFS/ CWD. Challenge experiments including isolates with different plasmid profiles are needed to determine whether virulence is associated with the 3.2 and $2.4 \mathrm{~kb}$ plasmids. Such association has been shown or assumed for plasmids of other fish pathogenic bacteria (Crosa et al. 1977, Sørum et al. 1988).

The results of the biochemical studies were generally in agreement with those of Pacha (1968), Holt (1987), Bernardet \& Kerouault (1989), and Schmidtke \& Carson (1995). Most reactions were slow and weak and it appeared to be important to use cultures not older than 2 to $3 \mathrm{~d}$ for most direct tests (e.g. flexirubin, catalase, oxidase). As for detection of cytochrome oxidase, Bernardet \& Kerouault (1989) drew attention to the need for a very sensitive test. This might explain why Holt (1987) and Pacha \& Porter (1968) regarded their strains as devoid of the enzyme using the method described by Gaby \& Hadley (1957). That method is regarded as less sensitive than the method of Kovács (1956, cited in Cowan 1974), the latter being the one used for preparation of the commercial filter papers/ discs used in the present study and by Bernardet \& Kerouault (1989). Discrepancies in detection of cytochrome oxidase according to the brand of the commercial product used have already been noted by Koski et al. (1993) for Flavobacterium columnare and F. psychrophilum.

Similarly, as for the ability to produce hydrogen sulphide, most of the isolates included in the study were positive in contrast to the findings of Pacha (1968), Pacha \& Porter (1968), Holt (1987) and Bernardet \& Kerouault (1989). Although almost the same method seems to have been applied, Pacha (1968), to whom the other authors refer, might have used $1 \%$ lead acetate for impregnation of filter papers (as reported by Pyle \& Shotts 1980), whereas $10 \%$ was used in the present study as prescribed by the Public Health Laboratory Service, National Collection of Type Cultures (1976). Consequently, the latter method might have been more sensitive than the method described by Pacha (1968) and Pacha \& Porter (1968).

With minor deviations, the API ZYM tests on the present isolates gave results comparable to those obtained by Bernardet \& Kerouault (1989) on French and American strains. Like the studies of Pacha \& Porter (1968), Holt (1987), and Bernardet \& Grimont (1989), the present study showed that the isolates examined were not able to degrade the simple and complex carbohydrates tested. The same held for Flavobacterium columnare as described by Bernardet (1989), but it should be noted that Griffin (1991) partially purified and characterized a chondroitin AC lyase from American strains of $F$. columnare and that the enzyme was able to degrade chondroitin sulphate $A$, chondroitin sulphate $\mathrm{C}$ and hyaluronic acid, all complex polysaccharides of connective tissue. Also, Holt (1987) cited Otis (1984) as having detected enzymes degrading chondroitin sulphate in American strains of F. psychrophilum. The findings indicate that the 2 pathogenic bacteria may possess enzymes able to degrade at least some specific, complex carbohydrates. Griffin (1991) suggested that such enzymes might be used invasively rather than nutritionally.

The distinct anaemia developed particularly by fry infected with Flavobacterium psychrophilum might to some degree be explained by the ability of the bac- 
terium to partially lyse and agglutinate rainbow trout erythrocytes. These effects could reflect proteolytic activity, which was also demonstrated in some of the other biochemical studies presented. Otis (1984, cited by Holt 1987) found some strains were able to degrade collagen, fibrinogen, and fish muscle extract. Pacha (1968) suggested proteolytic enzymes of $F$. psychrophilum to be important virulence factors, and in a recent study by Bertolini et al. (1994) different protease profiles were associated with differences in virulence. These and other possible virulence factors of $F$. psychrophilum and other cytophaga-like bacteria pathogenic for fish have recently been reviewed (Dalsgaard 1993).

As with Michel \& Bassalert (1982), Michel et al. (1984), and Høie (1991), the MIC dilution method was chosen for determining antibiotic sensitivity in the present study. This was also the method of choice of Carson et al. (1993) and of Schmidtke \& Carson (1995) studying Flavobacterium johnsoniae and F. psychrophilum, respectively. Instead of Müeller-Hinton agar, AOAE was chosen for the test, as the former does not sustain growth of $F$. psychrophilum. Cytophaga agar, which almost corresponds to AOAE, was claimed to contain sulfonamide inhibitors by Hawke \& Thune (1992). However, preliminary tests using Enterococcus faecalis ATCC 29121 showed that the zone diameters with this bacterium when tested on AOAE against sulfamerazin, trimethoprim, and trimethoprim+sulfa were comparable to the results obtained on Mueller-Hinton agar and within the control limits outlined by Casals \& Pringler (1991). In addition, Bernardet (1989) found 3 sulfonamide sensitive strains of $F$. columnare out of 9 strains examined using AOA.

The MIC values for oxytetracycline fell into 2 groups, one with higher sensitivity $\left(<0.05\right.$ to $\left.1.6 \mu \mathrm{g} \mathrm{ml}^{-1}\right)$, which was comparable to the results of Schmidtke \& Carson (1995), and one with lower sensitivity (6.3 to $12.5 \mu \mathrm{g}$ $\mathrm{ml}^{-1}$ ). Rangdale (1995) generally found higher MIC values. The MIC-values for oxolinic acid also fell in 2 groups, from 0.1 to $0.8 \mu \mathrm{g} \mathrm{ml}^{-1}$ and from 1.6 to $12.5 \mu \mathrm{g}$ $\mathrm{ml}^{-1}$, respectively. Schmidtke \& Carson (1995) found values lower than ours. The low sensitivity of Flavobacterium psychrophilum to a potentiated sulfonamide was comparable with the findings for sulfonamides of Pacha (1968), Bernardet \& Kerouault (1989), Schmidtke \& Carson (1995), and Rangdale (1995). Not surprisingly, the $\mathrm{MBC}$ values were somewhat higher than those of MIC for oxytetracycline. However, with oxolinic acid, the values of $\mathrm{MBC}$ were unexpectedly high relative to the MIC values.

According to the studies by Björklund \& Bylund (1990) on rainbow trout, maximum concentration of oxytetracycline following a single oral dose was $5.3 \mu \mathrm{g}$ $\mathrm{ml}^{-1}$ in serum and $4.0 \mu \mathrm{g} \mathrm{ml}^{-1}$ in muscle. Rogstad et al.
(1991) found MIC values of $7.1 \mu \mathrm{g} \mathrm{ml}^{-1}$ in skin and $19.1 \mathrm{\mu g} \mathrm{ml^{-1 }}$ in mucus. For oxolinic acid Rogstad et al. (1993) found maximum serum and muscle values of 0.99 and $5.5 \mu \mathrm{g} \mathrm{ml}^{-1}$, respectively. Bjørklund et al. (1992) found similar muscle values but serum values of $2.0 \mu \mathrm{g} \mathrm{ml}^{-1}$. Finally, Ishida (1992) demonstrated levels of 3.5 and $8.2 \mathrm{\mu g} \mathrm{ml}^{-1}$ in serum and muscle, respectively, and somewhat higher values for kidney and liver. Considering these tissue levels, it seems possible to combat at least those isolates belonging to the group with the lower MIC values described above with oxytetracycline and oxolinic acid. From the fish farms, however, there have been very few reports of succesful treatment with oxolinic acid; better results have been achieved using oxytetracycline (author's pers. obs.). The latter was also considered efficacious by Schachte (1983) and Wood (1974), and was found more effective than oxolinic acid by Baudin-Laurencin et al. (1989) in aquarium experiments. McCarthy et al. (1974) measured sulfadiazine levels in serum of about $70 \mu \mathrm{g} \mathrm{ml}^{-1}$ following a single oral dose, which should be sufficient for treating bacteria with MICs of 25 to $50 \mu \mathrm{g} \mathrm{ml}^{-1}$ such as were found in the present study. Shachte (1983) reported that sulphonamides should be effective in treatment of coldwater disease, but Wood (1974) suggested that levels beyond 50 to $60 \mu \mathrm{g} \mathrm{g}^{-1}$ were difficult to build up in coho salmon fry because of the lack of success experienced with feeding this drug to fry suffering from RTFS (Rangdale 1995, author's pers. obs.). The same may hold for oxolinic acid, i.e. the reported tissue levels for older fish are difficult to achieve in fry, particularly in diseased fry.

None of our isolates was able to grow at $25^{\circ} \mathrm{C}$, which is in accordance with the findings of Pacha \& Porter (1968). Further investigations of 6 of the isolates showed that incubation at $25^{\circ} \mathrm{C}$ for $24 \mathrm{~h}$ reduced the survival of the bacteria by 70 to $80 \%$, and none of the 6 isolates was able to survive at $26^{\circ} \mathrm{C}$ for more than $1 \mathrm{~d}$ (data not shown). Bernardet \& Kerouault (1989) found their strains grew scantily at $25^{\circ} \mathrm{C}$, but not above. Holt (1987) found 18 out of 25 isolates to grow slightly at $25^{\circ} \mathrm{C}$ but none of them grew at $30^{\circ} \mathrm{C}$, and Schmidtke \& Carson (1995) found that 18 out of 20 Australian isolates grew at $25^{\circ} \mathrm{C}$, but not at $30^{\circ} \mathrm{C}$. Thus it seems that the upper tolerance limit for the bacterium is close to $25^{\circ} \mathrm{C}$.

Concerning the tolerance to $\mathrm{NaCl}$, the present results were largely in accordance with those of Bernardet \& Kerouault (1989), Soltani \& Burke (1994), and Schmidtke \& Carson (1995). Pacha (1968) found all strains to grow in $0.8 \% \mathrm{NaCl}$ and that 6 out of 10 also grew in $1.0 \% \mathrm{NaCl}$. All strains studied by Holt (1987) were able to grow in $1.0 \%$ but not in $2.0 \% \mathrm{NaCl}$. Considering the above results, the limit of tolerance may be in the range of 0.8 to $0.9 \% \mathrm{NaCl}$, which is close to the total salt concentration of physiological saline and 
therefore fish tissue. The limit is far from the salinity of brackish/sea water ( 1.5 to $3.5 \%)$, where Flavobacterium psychrophilum has never been detected. Accordingly, Soltani \& Burke (1994) considered that salinities above $1 \%(\mathrm{NaCl}$ or seawater $)$ could reduce mortalities due to F. psychrophilum.

According to the findings of Bullock (1972), the morphology of colonies of 'Myxobacteria' (now Cytophagales; Reichenbach 1989) depends on the nutrient content of the agar, i.e. the lower the nutrient content. the more spreading the colonies. In the present study, however, generally only round, raised colonies with regular edges were found. This was likely due to the use of a protein-enriched medium in our study. Spreading colonies on very fresh and moist medium were also found by Christensen (1973, cited by Christensen 1977) and Henrichsen (1972), whereas Bernardei \& Kerouauli (1989) observed both types of colonies on the same agar plates.

The classification of the bacteria as Gram-negative in the present study is based more on EM results than on Gram staining, as the bacteria stained faintly. In histological studies different Gram stains always resulted in faint staining, whereas the bacteria were distinctly stained using the Warthin-Starry stain (Lorenzen et al. 1991) or immunohistochemical staining (Evensen \& Lorenzen 1996). With regard to shape and size of the cells, the present observations based on wet mount preparations were in accordance with the findings of Pacha (1968), Pacha \& Porter (1968), Holt (1987), and Bernardet \& Kerouault (1989). As expected from the slow, gliding movement of the bacteria, no fimbriae, pili or flagellae were demonstrated by EM. These results are in agreement with those of Holt (1987) and Holt et al. (1993). The vesicular tubules observed by Follett \& Webley (1965), Strohl \& Tait (1978), Humphrey et al. (1979) (on other gliding bacteria), Holt (1987) on Flavobacterium psychrophilum, and by us in some of the micrographs obtained in the present study probably represent the surface layer of the cells, detached during preparation for EM.

In conclusion, the present study demonstrated that Danish isolates and isolates from other European countries originating from fish with more or less typical clinical signs of CWD or RTFS were phenotypically very homogeneous and similar to the reference strain and to other strains from the USA and France described in other studies. Plasmid analysis, however, revealed some differences, and investigations on the plasmids, proteolytic activities and the ability to degrade specific complex carbohydrates are obviously needed to assess their relationship to virulence. Finally, challenge experiments with isolates from fish with clinical signs of CWD and RTFS are needed to determine whether the same pathogen causes the different disease signs.
Acknowledgements. Thanks are due to the late Dr K. HovindHougen, previously at the Danish Veterinary Laboratory in Copenhagen, for performing the electron microscopic studies of the bacteria, and to Mrs Brigitte Kerouault, INRA, Jouy-enJosas, France, for skillful technical assistance in DNA extraction. Mrs Kirsten Kaas at the Fish Disease Laboratory in Copenhagen is gratefully acknowledged for assistance in preparation of various media for the biochemical studies. The late Dr Poul Erk Vestergaard Jørgensen and Dr Niels Jørgen Olesen, Danish Veterinary Laboratory in Århus, are acknowledged for critically reviewing the manuscript.

\section{LITERATURE CITED}

Amos KH (1985) Procedures for the detection and identification of certain fish pathogens, 3rd edn. Fish Health Section, American Fishery Society, Corvallis, OR

Anacker RL, Ordal EJ (1955) Study of a bacteriophage infecting the myxobacterium Chondrococcus columnaris. J Bacteriol 70:738-741

Baudin-Laurencin F, Castric JC, Vigneulle $M$, Tixerant G (1989) La myxobactériose viscérale de la truite arc-en-ciel Salmo gairdneri R: une forme nouvelle de la maladie de l'eau froide à Cytophaga psychrophila. Bull Acad Vét Fr $62: 147-157$

Bernardet JF (1989) 'Flexibacter columnaris': first description in France and comparison with bacterial strains from other origins. Dis Aquat Org 6:37-44

Bernardet JF, Baudin-Laurencin F, Tixerant G (1988) First identification of 'Cytophaga psychrophila' in France. Bull Eur Assoc Fish Pathol 8:104-105

Bernardet JF, Campbell AC, Buswell JA (1990) Flexibacter maritimus is the agent of 'black patch necrosis' in Dover sole in Scotland. Dis Aquat Org 8:233-237

Bernardet JF, Grimont PAD (1989) Deoxyribonucleic acid relatedness and phenotypic characterization of Flexibacter columnaris sp. nov, nom. rev., Flexibacter psychrophilus sp. nov., nom. rev., and Flexibacter maritimus Wakabayashi, Hikida, and Masumura 1986. Int J Syst Bacteriol 39:346-354

Bernardet JF, Kerouault B (1989) Phenotypic and genomic studies of 'Cytophaga psychrophila' isolated from diseased rainbow trout (Oncorhynchus mykiss) in France. Appl Environ Microbiol 55:1796-1800

Bernardet JF, Segers P, Vancanneyt M, Berthe F, Kersters $K$, Vandamme P (1996) Cutting a Gordian knot: emended classification and description of the genus Flavobacterium, emended description of the family Flavobacteriaceae, and proposal of Flavobacterium hydatis nom. nov. (basynym. Cytophaga aquatilis Strohl and Tait 1978). Int J Syst Bacteriol $46(1): 128-148$

Bertolini JM, Wakabayashi $H$, Watral VG, Whipple MJ, Rohovec JS (1994) Electrophoretic detection of proteases from selected strains of Flexibacter psychrophilus and assessment of their variability. $J$ Aquat Anim Health 6: $224-233$

Björklund H, Bylund G (1990) Temperature-related absorption and excretion of oxytetracycline in rainbow trout (Salmo gairdneri R.). Aquaculture 84:363-372

Bjorklund HV, Enksson A, Bylund G (1992) Temperaturerelated absorption and excretion of oxolinic acid in rainbow trout (Oncorhynchus mykiss). Aquaculture 102:17-27

Borg AF (1960) Studies on myxobacteria associated with diseases in salmonid fishes. J Wildl Dis 8:1-85

Brenner DJ, MCWhorter AC, Leete Knutson JK, Steigerwalt AG (1982) Escherichia vulneris: a new species of Entero- 
bacteriaceae associated with human wounds. J Clin Microbiol 15:1133-1140

Bruno DW (1992) Cytophaga psychrophila (='Flexibacter psychrophilus') (Borg), histopathology associated with mortalities among farmed rainbow trout, Oncorhynchus mykiss (Walbaum) in the UK. Bull Eur Assoc Fish Pathol $12: 215-216$

Bullock GL (1972) Studies on selected myxobacteria pathogenic for fishes and bacterial gill disease in hatcheryreared salmonids. Technical Papers of The Bureau of Sport Fisheries and Wildlife, No. 60, Washington, DC

Bullock GL, Conroy DA, Snieszko SF (1971) Myxobacterioses. In: Snieszko SF, Axelrod HR (eds) Diseases of fishes. TFH Publications, Jersey City, NJ, p 60-88

Carson J, Schmidtke LM, Munday BL (1993) Cytophaga johnsonae: a putative skin pathogen of juvenile farmed barramundi, Lates calcarifer Bloch. J Fish Dis 16:209-218

Casals JB, Pringler N (1991) Anti bacterial fungal sensitivity testing using neo-sensitabs. Rosco Diagnostica, Taastrup

Christensen PJ (1977) The history, biology, and taxonomy of the Cytophaga group. Can J Microbiol 23:1599-1653

Conrad JF, DeCew M (1967) Observations on deformed juvenile coho salmon. Research Briefs, Fish Commission of Oregon 13:129

Cowan ST (1974) Cowan and Steel's manual for the identification of medical bacteria. Cambridge University Press, Cambridge

Crosa JH, Schiewe MH, Falkow S (1977) Evidence for plasmid contribution to the virulence of the fish pathogen Vibrio anguillarum. Infect Immun 18(2):509-513

Dalsgaard 1 (1993) Virulence mechanisms in Cytophaga psychrophila and other cytophaga-like bacteria pathogenic for fish. Annu Rev Fish Dis 3:127-144

Dalsgaard I, Horlyck V (1990) Koldtvandssyge eller vintersår hos ørreder [Coldwater disease or winter lesions in trout]. Ferskvandsfiskeribladet 88:118-120

Davis HS (1946) Care and diseases of trout. Research Report no 12:63-66, US Fish and Wildlife Service, US Dept of the Interior, US Government Printing Office (cited in Bullock et al. 1971)

Evensen $\varnothing$. Lorenzen E (1996) An immunohistochemical study of Flexibacter psychrophilus infection in experimentally and naturally infected rainbow trout (Onchorhynchus mykiss) fry. Dis Aquat Org 25:53-61

Follett EAC. Webley DM (1965) An electron microscope study of the cell surface of Cytophaga johnsonil and some observations on related organisms. Antonie Leeuwenhoek 31 $361-382$

Frasca JM, Parks VR (1965) A routine technique for doublestaining ultrathin sections using uranyl \& lead salts. J Cell Biol 25:157-161

Gaby WL, Hadley C (1957) Practical laboratory test for the identification of Pseudomonas aeruginosa. J Bacteriol 74 : 356-358

Griffin BR (1991) Characteristics of a chondroitin AC lyase produced by Cytophaga columnaris. Trans Am Fish Soc 120:391-395

Grimont PAD, Popoff MY, Grimont F, Coynault C, Lemelin M (1980) Reproducibility and correlation study of three deoxyribonucleic acid hybridization procedures. Curr Microbiol 4:325-330

Hawke JP, Thune RL (1992) Systemic isolation and antimicrobial susceptibility of Cytophaga columnaris from commercially reared channel catfish. J Aquat Anim Health 4 : 109-113

Henrichsen J (1972) Bacterial surface translocation: a survey and a classification. Bacteriol Rev 36:478-503
Holt RA (1987) Cytophaga psychrophila, the causative agent of bacterial cold-water disease in salmonid fish. PhD thesis, Oregon State University, Corvallis

Holt RA, Amandi A, Rohovec JS, Fryer JL (1989) Relation of water temperature to bacterial cold-water disease in coho salmon, chinook salmon, and rainbow trout. J Aquat Anim Health 1:94-101

Holt RA, Rohovec JS, Fryer JL (1993) Bacterial cold-water disease. In: Inglis V, Roberts RJ, Bromage NR (eds) Bacterial diseases of fish. Blackwell Scientific Publications, Oxford, p 3-22

Humphrey BA, Dickson MR, Marshall KC (1979) Physicochemical and in situ observations on the adhesion of gliding bacteria to surfaces. Arch Mikrobiol 120:231-238

Høie S (1991) Resistensundersøkelser av Aeromonas salmonicida subsp. salmonicida stammer [Resistance patterns of Aeromonas salmonicida subsp. salmonicida strains]. Nor Veterinærtidsskr 103:527-528

Ishida N (1992) Tissue levels of oxolinic acid afte oral or intravascular administration to freshwater and seawater rainbow trout. Aquaculture 102:9-15

Ishiguro EE, Ainsworth T, Trust TJ, Kay WW (1985) Congo red agar, a differential medium for Aeromonas salmonicida, detects the presence of the cell surface protein array involved in virulence. J Bacteriol 164:1233-1237

Johnson JL, Chilton WS (1966) Galactosamine glycan of Chondrococcus columnaris. Science 152:1247-1248

Kado CI, Liu ST (1981) Rapid procedure for detection and isolation of large and small plasmids. J Bacteriol 145; $1365-1373$

Kent ML, Groff JM, Morrison JK, Yasutake WT, Holt RA (1989) Spiral swimming behaviour due to cranial and vertebral lesions associated with Cytophaga psychrophila infections in salmonid fishes. Dis Aquat Org 6 : 11-16

Koski P, Hirvelä-Koski V, Bernardet JF (1993) Flexibacter columnaris infection in arctic char (Salvelinus alpinus (L.)). First isolation in Finland. Bull Eur Assoc Fish Pathol 13:66-69

Lehmann J, Mock D, Stürenberg FJ (1988) Zur Ausbreitung der Bakteriellen Kaltwasserkrankheit (BKK) in NordrheinWestfalen. Fischer und Teichwirt 7:206-207

Lehmann J, Mock D, Stürenberg FJ, Bernardet JF (1991) First isolation of Cytophaga psychrophila from a systemic disease in eel and cyprinids. Dis Aquat Org 10:217-220

Lior H, Patel A (1987) Improved toluidine blue-DNA agar for detection of DNA hydrolysis by campylobacters. J Clin Microbiol 25:2030-2031

Lorenzen $E$ (1993) The importance of the brand of the beef extract in relation to the growth of Flexibacter psychrophilus in Anacker \& Ordal's medium. Bull Eur Assoc Fish Pathol 13:64-65

Lorenzen E, Dalsgaard I, From J, Hansen EM, Hørlyck V, Korsholm $H_{1}$ Mellergaard S, Olesen NJ (1991) Preliminary investigations of fry mortality syndrome in rainbow trout. Bull Eur Assoc Fish Pathol 11:77-79

Lorenzen E, Karas N (1992) Detection of Flexibacter psychrophilus by immunofluorescence in fish suffering from fry mortality syndrome: a rapid diagnostic method. Dis Aquat Org 13:231-234

Macrina FL, Kopecko DJ, Jones KR, Ayers DJ, McCowen SM (1978) A multiple plasmid-containing Escherichia coli strain: convenient source of size reference plasmid molecules. Plasmid 1:421-434

Maniatis T, Fritsch EF, Sambrook J (1989) Molecular cloning: a laboratory manual. Cold Spring Harbor Laboratory Press, NY 
McCarthy DH, Stevenson JP, Salsbury AW (1974) A comparative pharmaco-kinetic study of seven sulphonamides and a sulphonamide potentiatior, trimethoprim, in rainbow trout (Salmo gairdnen, Richardson). Aquaculture 4 $299-303$

Meyers TR (1989) Apparent chronic bacterial myeloencephalitis in hatchery reared juvenile coho salmon Oncorhynchus kisutch in Alaska. Dis Aquat Org 6:217-219

Michel C, Bassalert JF (1982) Influence de la température sur les résultats de l'antibiogramme pratiqué par la méthode de diffusion en ichtyopathologie. Ann Rech Vét 13(3): $245-250$

Michel C, Suprin L, Kinkelin P (1984) A microdilution method for drug sensitivity testing of fish associated bacteria at $22^{\circ} \mathrm{C}$. J Appl Bacteriol 57:15-21

Mourey A, Kilbertus G (1976) Simple media containing stabilized tributyrin for demonstrating lipolytic bacteria in foods and soils. J Appl Bacteriol 40:47-51

Olsen JE, Baggesen DL, Nielsen BB, Larsen HE (1990) The prevalence of plasmids in Danish bovine and human isolates of Salmonella dublin. APMIS 98:735-740

Pacha RE (1968) Characteristics of Cytophaga psychrophila (Borg) isolated during outbreaks of bacterial cold-water disease. Appl Microbiol 16:97-101

Pacha RE, Porter S (1968) Characteristics of myxobacteria isolated from the surface of freshwater fish. Appl Microbiol 16:1901-1906

Popoff MY, Coynault C, Kiredjian M, Lemelin M (1981) Polynucleotide sequence relatedness among motile Aeromonas species. Curr Microbiol 5:109-114

Public Health Laboratory Service (1976) Manual of media and methods used for the computer identification of gramnegative bacteria. National Collection of Type Cultures, Central Public Health Laboratory, London

Pyle SW, Shotts EB (1980) A new approach for differentiating Flexibacteria isolated from cold-water and warmwater fish. Can J Fish Aquat Sci 37:1040-1042

Rangdale RE (1995) Studies on rainbow trout fry syndrome (RTFS). PhD thesis, Fish Disease Laboratory, Weymouth

Reichenbach H (1989) Cytophagales. In: Stanley JT, Bryant MP, Pfennig N, Holt JG (eds) Bergey's manual of systematic bacteriology, Vol 3. Williams \& Williams, Baltimore

Reichenbach H, Dworkin M (1981) The order Cytophagales (with addenda on the genera Herpetosiphon, Saprospira, and Flexithrix). In: Starr MP, Stolph $\mathrm{H}$, Trupher HG, Balows A, Schlegel HG (eds) The prokaryotes, Vol 1. Springer-Verlag, New York, p 356-379

Reynolds ES (1963) The use of lead citrate at a high $\mathrm{pH}$ as an electron opaque stain in electron microscopy. J Cell Biol 17:208-212

Rogstad A, Ellingsen OF, Syvertsen C (1993) Pharmacokinetics and bioavailability of flumequine and oxolinic acid after various routes of administration to Atlantic salmon in seawater. Aquaculture 110:207-220

Rogstad A, Hormazabal V, Ellingsen OF, Rasmussen KE (1991) Pharmacokinetic study of oxytetracycline in fish. I. Absorption, distribution and accumulation in rainbow trout in freshwater. Aquaculture 96:219-226

Rochelle PA, Fry JC, Day MJ, Bale MJ (1985) An accurate method for estimating sizes of small and large plasmids

Editorial responsibility: Trevor Evelyn

Nanaimo, British Columbia, Canada and DNA fragments by gel electrophoresis. J Gen Microbiol 132:53-59

Sahm DF, Washington II JA (1991) Antibacterial susceptibility tests: dilution methods. In: Balows A (ed) Manual of clinical microbiolagy, 5th edn. ASM, Washington, DC, $p$ $1105-1116$

Santos Y, Huntly PJ, Turnbull A, Hastings TS (1992) Isolation of Cytophaga psychrophila (Flexibacter psychrophilus) in association with rainbow trout mortality in the United Kingdom. Bull Eur Assoc Fish Pathol 12:209-210

Sarti M, Giorgetti G, Manfrin A (1992) Method for the rapid diagnosis of visceral myxobacteriosis in reared trout in Italy. Bull Eur Assoc Fish Pathol 12:53

Schachte JG (1983) Coldwater disease. In: Meyer FP, Warren JW, Carey TGA (eds) A guide to integrated fish health management in the great lakes basin. Great Lakes Fishery Commission, Ann Arbor, Ml, p 193-197

Schmidtke LM, Carson J (1995) Characteristics of Flexibacter psychrophilus isolated from Atlantic salmon in Australia. Dis Aquat Org 21:157-161

Sierra G (1957) A simple method for the detection of lipolvtic activity of microorganisms and some observations on the influence of the contact between cells and fatty substrates. Antonie Leeuwenhoek 23:15-22

Soltani M, Burke CM (1994) Responses of fish-pathogenic Cytophaga/Flexibacter-like bacteria (CFLB) to environmental conditions. Bull Eur Assoc Fish Pathol 14:185-187

Strohl WR, Tait LR (1978) Cytophaga aquatilis sp. nov., a facultative anaerobe isolated from the gills of freshwater fish. Int $J$ Syst Bacteriol 28:293-303

Sørum H, Poppe TT, Olsvik $\varnothing$ (1988) Plasmids in Vibrio salmonicida isolated from salmonids with haemorrhagic syndrome (Hitra disease). J Clin Microbiol 26(9): 1679-1683

Threlfall EJ, Rowe B, Ferguson JL, Ward LR (1986) Characterization of plasmids conferring resistance to gentamycin and apramycin in strains of Salmonella typhimurium phage type 204c isolated in Britain. J Hyg 97:419-426

Titball RW, Munn CB (1981) Evidence for two haemolytic activities from Aeromonas salmonicida. FEMS Microbiol Lett 12:27-30

Toranzo AE, Barja JL (1993) Fry mortality syndrome (FMS) in Spain. Isolation of the causative bacterium Flexibacter psychrophilus. Bull Eur Assoc Fish Pathol 13:30-32

Wakabayashi $H$, Toyama $T$, lida $T$ (1994) A study on serotyping of Cytophaga psychrophila isolated from fishes in Japan. Fish Pathol (Gyobyo Kenkyu) 29:101-104

Weis J (1987) Über das Vorkommen einer Kaltwasserkrankheit bei Regenbogenforellen, Salmo gairdneri. Tierärztl Umschau 42:575-577

Wiklund T, Kaas K, Lönnström L, Dalsgaard I (1994) Isolation of Cytophaga psychrophila (Flexibacter psychrophilus) from wild and farmed rainbow trout (Oncorhynchus mykiss) in Finland. Bull Eur Assoc Fish Pathol 14:44-46

Willis AT (1960) The lipolytic activity of some clostridia. J Pathol Bacteriol 80:379-390

Wood EM, Yasutake TW (1956) Histopathology of fish. III. Peduncle ('cold-water') disease. Prog Fish-Cult 18:58-61

Wood JW (1974) Diseases of Pacific salmon: their prevention and treatment, 2nd edn. Hatchery division. Washington Department of Fisheries, Olympia, WA

Submitted: July 21, 1995; Accepted: September 25, 1997 Proofs received from author(s): December 22, 1997 